Jurnal Akuntansi dan Bisnis: Jurnal Program Studi Akuntansi 7 (2) November 2021

ISSN 2443-3071 (Print) ISSN 2503-0337 (Online)

DOI: $10.31289 /$ iab.v7i2.5388

JURNAL AKUNTANSI DAN BISNIS

Jurnal Program Studi Akuntansi

Available online http://ojs.uma.ac.id/index.php/jurnalakundanbisnis

\title{
Indeks Transparansi Pengelolaan Anggaran Daerah: Bagaimana Perkembangannya?
}

\section{Regional Budget Management Transparency Index: How is it Progressing?}

\author{
Nulailah \& Syamsul* \\ Program Studi Akuntansi, Sekolah Tinggi Ilmu Ekonomi Panca Bhakti Palu, Indonesia
}

Diterima: 16 Juni 2021 Direview: 16 Juni 2021 Disetujui: 29 September 2021

*Coresponding Email: syamsulsyahrir@gmal.com

\begin{abstract}
Abstrak
Tujuan penelitian ini adalah menakar transparansi pengelolaan anggaran daerah (TPAD). Jenis penelitian ini adalah penelitian deskriptif, dengan menggunakan teknik pengumpulan data dokumentansi. Data yang dianalisis adalah data pengelolaan anggaran daerah, yang diperoleh melalui pengamatan pada website resmi pemerintah daerah di Indonesia. Hasil analisis menunjukkan peringkat pertama indeks TPAD diraih oleh Pemprov Sumatera Barat, peringkat kedua ditempati oleh Pemprov Riau, dan peringkat ketigia diduduki oleh Pemprov Kalimantan Selatan. Selain itu, ditemukan juga bahwa nilai rata-rata indeks TPAD sebesar 24,24 persen. Artinya, secara keseluruhan kadar TPAD masih termasuk dalam kualifikasi tidak cukup (insufficient), dengan kata lain pengelolaan anggaran daerah di Indonesia masih sangat tidak transparan. Meskipun demikian, penelitian ini juga memperlihatkan bahwa indeks TPAD di Indonesia terus membaik dari tahun ke tahun.

Kata Kunci: transparansi; anggaran daerah; aksi pencegahan dan pemberantasan korupsi
\end{abstract}

\begin{abstract}
The purpose of this research is to measure the transparency of regional budget management (TPAD). This type of research is descriptive research, using documentation data collection techniques. The data analyzed is regional budget management data, which is obtained through observations on the official website of local governments in Indonesia. The results of the analysis show that the first rank of the TPAD index was achieved by the Provincial Government of West Sumatra, the second rank was occupied by the Provincial Government of Riau, and the third rank was occupied by the Provincial Government of South Kalimantan. In addition, it was also found that the average value of the TPAD index was 24.24 percent. This means that the overall level of TPAD is still classified as insufficient, in other words, the management of regional budgets in Indonesia is still very non-transparent. However, this study also shows that the TPAD index in Indonesia continues to improve from year to year.
\end{abstract}

Keywords: transparency; local budget; anti-corruption action

How to Cite: Nurlailah \& Syamsul (2021). Indeks Transparansi Pengelolaan Anggaran Daerah: Bagaimana Perkembangannya? Jurnal Akuntansi dan Bisnis: Jurnal Program Studi Akuntansi, 7(2), 180-195. 


\section{PENDAHULUAN}

Di Indonesia, upaya pencegahan dan pemberantasan korupsi pada tataran pemerintah daerah, ditetapkan dalam Instruksi Presiden Republik Indonesia (Inpres RI) Nomor 7 Tahun 2015. Secara khsus, pada poin 32 setiap pemerintah daerah untuk melaksanakan aksi peningkatan transparansi pengelolaan anggaran daerah (TPAD) melalui website resmi mereka. Instruski ini, kembali mempertegas beberapa regulasi sebelumnya tentang pentingnya penerapan TPAD (Undang-Undang Nomor 14 Tahun 2008; Instruksi Menteri Dalam Negeri Republik Indonesia Nomor 188.52/1797/SJ/2012). Intinya, pada tataran regulasi yang ada telah mencerminkan komitmen pemerintah untuk mengedepankan prinsip transparansi demi terbentuknya penyelenggaraan pemerintahan yang baik dan bersih.

Meskipun demikian, berdasarkan data yang diakses dari laman website KPK pada tanggal 03 Oktober 2020 memperlihatkan bahwa kasus korupsi yang tindak KPK berdasarkan wilayahnya pada tahun 2004-2020 sebanyak 1075, tertinggi di wilayah pemerintah pusat sebanyak 336 kasus, diikuti Pulau Jawa 330 kasus, kemudian Pulau Sumatera 244 kasus (KPK, 2020). Kemudian, Egi Primayogo selaku peneliti Indonesia Corruption Watch (ICW), menyampaikan hasil observasi mereka terhadap kasus korupsi di Indonesia, bahwa dalam kurun waktu 14 tahun dari 2004 sampai 2018 sebanyak 104 kepala daerah tersangkut skandal korupsi, angka tertinggi tahun 2018 sebanyak 14 perkara (Habibie, 2018). Disisi lain, Pusparisa menyebutkan berdasarkan data yang dipublis KPK, bahwa dari tahun 2004 hingga 2019 sebanyak 114 kepala daerah terbentur persoalan korupsi, yaitu sebanyak 17 Gubernur, 23 Wali Kota, dan 74 Bupati (Pusparisa, 2019). Selain itu, Agus Sutarjo selaku ketua KPK mengungkapkan bahwa dari 34 provinsi di Indonesia, sebanyak 22 kepala daerahnya tersandung kasus korupsi (Nugraha, 2019). Intinya, angka ini menginformasikan bahwa kasus korupsi yang melibatkan kepada daerah di Indonesia masih sangat tinggi.

Selanjutnya, hasil penelitian Alwahidi and Darwanis (2019) pada 224 kabupaten/kota di Indonesia, menunjukkan tingkat TPAD pemerintah kabupaten/kota melalui website resmi mereka sebesar 10,85 persen. Kemudian, Nuryani and Firmansyah (2020) menemukan tingkat transparansi keuangan pemerintah kabupaten/kota di Pulau Jawa sebesar 24,76. Adriana and Ritonga (2018) menjelaskan tingkat TPAD pemeritah kabupaten di Pulau Jawa sebesar 19,59 persen. Begitupula, Syamsul and Ritonga (2017) menunjukkan bahwa tingkat transparansi pengelolaan keuangan daerah pemerintah provinsi (Pemprov) sebesar 17,24 persen. Begitupula, Syamsul (2020) menunjukkan rerata indeks TPAD di Indonesia, sebesar 24,36 persen. Sederhananya, temuan penelitian tersebut menginformasikan bahwa tingkat TPAD di Indonesia masih rendah, dapat dikatakan pengelolaan keuangan pemerintah daerah dilaksanakan secara tidak transparan.

Sayangnya, penelitian yang ada belum mempertimbangkan kriteria kelengkapan informasi (dokumen) yang diungkapkan oleh pemerintah daerah pada website mereka. Padahal, kriteria ini penting untuk dijadikan acuan dalam menilai kualitas (kebermanfaatan) sebuah informasi yang disajikan. Singkatnya, meskipun informasi pengelolaan keuangan daerah itu tersedia, dapat diakses, dan tepat waktu disajikan, tetapi tidak lengkap, tentunya berimplikasi pada tidak efektifnya dijadikan rujukan dalam pengambilan keputusan. Selain itu, mayoritas penelitian sebelumnya dalam mengukur tingkat transparansi pemerintah, hanya terbatas pada satu tahun anggaran. Sehingga, tidak menunjukkan informasi tentang perkembangan transparansi pemerintah dari tahun ke tahun, apakah membaik atau malah sebaliknya, semakin memburuk? Penelitian ini hadir untuk melengkapi penelitian sebelumnya, dengan memasukkan kriteria kelengkapan 
publikasi dalam menilai indeks TPAD, sehingga tidak hanya kuantitas semata, tetapi kualitas dari sebuah informasi juga dipertimbangkan. Disisi lain, penelitian ini menggambarkan tingkat keberhasilan aksi peningkatan TPAD Indonesia yang lebih akurat, lengkap, dan terkini. Sehingga, lebih dapat diandalkan dalam pengambilan keputusan, dalam mengevaluasi capaian pelaksanaan TPAD sekarang ini.

Meijer (2013) menyatakan bahwa transparansi adalah sebagai bentuk ketersediaan informasi tentang pelaku pertama yang memungkinkan pelaku kedua menilai aktivitas atau kinerja pelaku pertama. Senada dengan itu, Hoa and Garcia (2017) juga berpendapat bahwa transparansi adalah bentuk kelapangan pengguna kebijakan untuk mendapatkan saluran informasi, dan informasi itu dipublikasikan menggunakan sarana publik atau dengan cara lain. Baur dan Grimes (2012) berpendapat bahwa transparansi adalah ketersediaan, dan kemudahan bagi para aktor, baik internal maupun eksternal untuk mengakses dan menyebarkan informasi yang relevan untuk dievaluasi, baik dalam hal aturan, proses maupun capaiannya. Esteves de Araujo and Tejedo-Romero (2016) mengungkapkan bahwa transparansi merupakan rancangan yang ekstensif berkaitan dengan keberadaan informasi, aksesibilitas, dan kebermanfaatannya kepada warga (publik). Kaufmann \& Kraay (2002) mendefinisikan transparansi sebagai peningkatan arus informasi ekonomi, sosial dan politik yang tepat waktu, dapat diandalkan, dan dapat diakses oleh semua pihak yang relevan. Oleh karena itu, transparansi adalah tersedianya informasi tentang lembaga pemerintah yang membolehkan masyarakat untuk memperhatikan dan mengevaluasi kinerja organisasi pemerintah (Grimmelikhuijsen, 2012; A. Meijer, 2013), yang diungkapkan tepat waktu (Ritonga \& Syamsul, 2016; Syamsul, 2020; Syamsul \& Ritonga, 2017), dan disajikan dengan lengkap (menyeluruh).

Menurut Puron-Cid et al., (2019) transparansi adalah sebuah solusi dalam mereduksi kemungkinan terjadinya kasus korupsi, mendorong kinerja keuangan, dan dapat meningkatkan kepercayaan masyarakat kepada pemerintah. Transparansi juga dimaknai dapat meningkatkan akuntabilitas pemerintah dan menguatkan demokrasi (A. J. Meijer et al., 2012; Wei Wu, Liang Ma, 2017). Selanjutnya, Laswad et al., (2005) mengatakan bahwa publikasi laporan keuangan di internet adalah bentuk transparansi dan akuntabilitas pemerintah daerah. Saat ini, menurut Styles \& Tennyson (2007) bahwa internet merupakan media yang paling mudah dijangkau oleh publik dan yang paling cost effective bagi pemerintah untuk memberikan informasi kepada semua pihak.

Transparansi telah menjadi sebuah keharusan bagi pemerintah di Indonesia semenjak ditetapkannya Undang-Undang Nomor 14 Tahun 2008 tentang Keterbukaan Informasi publik. Undang-undang ini, kemudian ditindaklanjuti dengan diterbitkannya Peraturan Pemerintah Nomor 61 Tahun 2010 tentang Pelaksanaan UU No. 14 Tahun 2008 tentang Keterbukaan Informasi Publik, Peraturan Menteri Dalam Negeri Nomor 35 Tahun 2010 tentang Pedoman Pengelolaan Pelayanan Informasi dan Dokumentasi di Lingkungan Kementerian Dalam Negeri dan Pemerintah Daerah. Kemudian, penerapannya Menteri Dalam Negeri menerbitkan Instruksi Menteri Dalam Negeri Republik Indonesia Nomor 188.52/1797/37/SJ/2012 tentang Peningkatan Transparansi Pengelolaan Anggaran Daerah. Dikuatkan dengan munculnya Instruksi Presiden Republik Indonesia No. 7 Tahun 2015 tentang Aksi dan Pencegahan dan Pemberantasan Korupsi. Sebagai tindak lanjut, Kementrian Dalam Negeri mengeluarkan Surat Edaran No. 900/1843/Keuda/IX/2015 Perihal TPAD. Beberapa regulasi dan kebijakan tersebut, memperjelas komitmen pemerintah untuk memperbaiki transparansi, utamanya menguatkan pentingnya peningkatan TPAD (Syamsul, 2020). 


\section{METODE PENELITIAN}

Jenis penelitian ini adalah deskriptif. Teknik pengumpulan data yang digunakan pada penelitian ini adalah teknik pengumpulan data dokumentasi. Penelitian ini menggunakan metoda content analysis (analisis isi). Menurut Moleong (2013) kajian isi adalah penggunaan teknik apapun dalam menarik kesimpulan dengan usaha menemukan karakterisik informasi yang dilakukan secara objektif dan sistematis. Penelitian ini menganalisis isi informasi yang disampaikan lewat website resmi pemerintah daerah (34 Provinsi) di Indonesia. Penelurusan informasi pada website pemerintah daerah dilakukan pada Bulan Mei-Juni 2021. Informasi yang telusuri adalah informasi peningkatan TPAD, yang terdiri dari 12 (dua belas) indikator, sesuai dengan yang tertera dalam Inpres RI Nomor 7 Tahun 2015 (lihat lampiran). Penilaian indikator TPAD didasarkan pada kriteria informasi ditetapkan oleh (Ritonga \& Syamsul, 2016), yaitu ketersediaan, aksesibilitas, ketepatan waktu, dengan menambahkan kriteria kelengkapan publikasi sesuai arahan dari penelitian (Syamsul, 2020).

Perhitungan indeks TPAD, yaitu pengukuran menggunakan skor dikotomi, jika suatu indikator TPAD tersedia, dapat diakses, tepat waktu, lengkap dipublikasikan pada website pemerintah daerah diberi nilai masing-masing 1 untuk setiap kriteria dan jika sebaliknya diberi nilai masing-masing 0 untuk setiap kriteria. Skor yang diperoleh untuk setiap kriteria masingmasing dikalikan 0,25. Hasilnya, kemudian dijumlahkan untuk memperoleh skor total untuk setiap indikator. Skor yang diperoleh setiap indikator dijumlahkan untuk mendapatkan skor total untuk setiap pemerintah daerah. Terakhir, menghitung indeks TPAD dengan cara membagi total skor yang diperoleh dengan total skor yang diharapkan dapat diperoleh oleh setiap pemerintah daerah, kemudian dikalikan seratus. Selanjutnya, menghitung tingkat perkembangan indeks TPAD dari periode ke periode. Selain itu, juga dilakukan pengelompokan dengan melihat nilai rata-rata indeks TPAD berdasarkan tingkat keterbukaan anggaran yang dikeluarkan oleh International Budget Partnership (IBP) Tahun 2019.

\section{HASIL DAN PEMBAHASAN}

Penelitian ini menakar kadar keberhasilan peningkatan transparansi pengelolaan anggaran daerah (TPAD), yang secara khusus dituangkan di dalam Inpres RI Nomor 7 Tahun 2015 tentang aksi pencegahan dan pemberantasan korupsi. Berdasarkan pada tabel 1, terlihat bahwa indeks TPAD tahun 2016 tertinggi ditempati oleh Pemprov Kalimatan Selatan, disusul Pemprov Sumatera Barat dan Pemprov Riau. Kemudian, nilai indeks TPAD terendah diduduki oleh 16 pemerintah daerah, yaitu Pemprov Sumatera Utara, Bengkulu, DI Yogyakarta, Kalimantan Utara, Sulawesi Tengah, Sulawesi Tenggara, Maluku Utara, Banten, Maluku, Gorontalo, Bali, Kepulauan Riau, Sulawesi Selatan, Papua Barat, Sulawesi Barat, dan Sulawesi Utara. Kondisi ini menunjukkan bahwa pada tahun 2016 mayoritas pemerintah daerah di Indonesia tidak mempublikasikan informasi pengelolaan anggaran daerah pada webste mereka. Selain itu, apabila dilihat dari nilai rata-rata indeks TPAD pada tahun 2016 sebesar 19,36 persen. Angka ini, menunjukkan bahwa pengelolaan anggaran daerah pada tahun 2016 termasuk dalam kualifikasi sangat tidak transparan (Adiloglu \& Vuran, 2012).

Selanjutnya, pada tabel 1 indikator TPAD yang paling banyak dipenuhi oleh pemerintah daerah pada tahun 2016 adalah informasi tentang Opini atas Laporan Keuangan Pemerintah Daerah (LKPD) dan informasi tentang Ringkasan DPA-SKPD. Disisi lain, indikator TPAD yang paling sedikit dipenuhi yaitu informasi tentang Rancangan Peraturan Daerah tentang APBD. Artinya, sebagian besar pemerintah daerah belum 
mempublikasikan informasi pengelolaan anggaran daerah tentang Rancangan Peraturan Daerah tentang APBD pada website mereka.

Tabel 1. Indeks Transparansi Pengelolaan Anggaran (TPAD) Tahun 2016

\begin{tabular}{|c|c|c|c|c|c|c|c|c|c|c|c|c|c|c|}
\hline \multirow{2}{*}{ Pemprov } & \multicolumn{13}{|c|}{ Indikator TPAD Tahun 2016} & \multirow{2}{*}{ Indeks } \\
\hline & 1 & 2 & 3 & 4 & 5 & 6 & 7 & 8 & 9 & 10 & 11 & 12 & Total & \\
\hline Aceh & 0,5 & - & - & 0,8 & - & - & 0,5 & - & 0,5 & - & 0,8 & - & 3,00 & 25,00 \\
\hline Sumatera Utara & - & - & - & - & - & - & - & - & - & - & - & - & 0,00 & 0,00 \\
\hline Sumatera Barat & 0,8 & 0,8 & 0,8 & 0,8 & 0,8 & 0,8 & 0,8 & 0,8 & 0,8 & 0,8 & 0,8 & 0,8 & 9,00 & 75,00 \\
\hline Riau & 0,8 & 0,8 & 0,5 & 0,8 & 0,8 & 0,8 & 1,0 & 0,8 & 0,5 & 0,8 & 0,8 & 1,0 & 9,00 & 75,00 \\
\hline Jambi & 0,8 & - & - & 0,5 & - & - & - & - & 0,8 & 0,8 & 0,5 & 0,8 & 4,00 & 33,33 \\
\hline Sumatera Selatan & - & - & - & - & - & - & 0,8 & - & - & - & - & - & 0,75 & 6,25 \\
\hline Bengkulu & - & - & - & - & - & - & - & - & - & - & - & - & 0,00 & 0,00 \\
\hline Lampung & - & - & - & 0,3 & 0,3 & 0,3 & 0,3 & 0,3 & - & - & - & 0,3 & 1,50 & 12,50 \\
\hline Bangka Belitung & 0,8 & 0,8 & - & - & - & 0,8 & 0,8 & - & 0,8 & 0,8 & - & - & 4,50 & 37,50 \\
\hline Kepulauan Riau & - & - & - & - & - & - & - & - & - & - & - & - & 0,00 & 0,00 \\
\hline Banten & - & - & - & - & - & - & - & - & - & - & - & - & 0,00 & 0,00 \\
\hline DKI Jakarta & - & - & - & - & - & - & - & - & - & 1,0 & - & - & 1,00 & 8,33 \\
\hline Jawa Barat & - & - & - & 1,0 & 0,8 & 1,0 & 1,0 & 1,0 & - & - & 0,8 & 0,8 & 6,25 & 52,08 \\
\hline Jawa Tengah & - & - & - & 1,0 & - & 1,0 & 1,0 & 1,0 & - & - & 0,8 & - & 4,75 & 39,58 \\
\hline DI Yogyakarta & - & - & - & - & - & - & - & - & - & - & - & - & 0,00 & 0,00 \\
\hline Jawa Timur & 0,5 & 0,5 & 0,8 & 0,8 & 0,8 & 0,8 & 0,5 & 0,5 & 0,5 & 0,5 & 0,3 & 1,0 & 7,25 & 60,42 \\
\hline Kalimantan Barat & 1,0 & - & - & - & - & - & - & - & - & - & 1,0 & 1,0 & 3,00 & 25,00 \\
\hline Kalimantan ' & - & - & - & - & - & - & - & - & - & - & - & - & 0,00 & 0,00 \\
\hline Kalimantar & 1,0 & - & 0,5 & 1,0 & 0,8 & 0,5 & 1,0 & 0,8 & - & - & - & 4,0 & 9,50 & 79,17 \\
\hline Kalimantan Timur & 1,0 & 1,0 & - & 1,0 & 0,8 & 0,5 & 1,0 & 1,0 & - & - & 1,0 & 0,8 & 8,00 & 66,67 \\
\hline Kalimantan Utara & - & - & - & - & - & - & - & - & - & - & - & - & 0,00 & 0,00 \\
\hline Sulawesi Utara & - & - & - & - & - & - & - & - & - & - & - & - & 0,00 & 0,00 \\
\hline Gorontalo & - & - & - & - & - & - & - & - & - & - & - & - & 0,00 & 0,00 \\
\hline Sulawesi Tengah & - & - & - & - & - & - & - & - & - & - & - & - & 0,00 & 0,00 \\
\hline Sulawesi Selatan & - & - & - & - & - & - & - & - & - & - & - & - & 0,00 & 0,00 \\
\hline Sulawesi Tenggara & - & - & - & - & - & - & - & - & - & - & - & - & 0,00 & 0,00 \\
\hline Sulawesi Barat & - & - & - & - & - & - & - & - & - & - & - & - & 0,00 & 0,00 \\
\hline Bali & - & - & - & - & - & - & - & - & - & - & - & - & 0,00 & 0,00 \\
\hline Nusa Tenggara Barat & - & - & - & - & - & 0,5 & 0,8 & 0,8 & - & - & - & - & 2,00 & 16,67 \\
\hline Nusa Tenggara Timur & 0,8 & 0,8 & 0,5 & 0,5 & - & - & 0,8 & 0,8 & - & - & - & - & 4,00 & 33,33 \\
\hline Maluku & - & - & - & - & - & - & - & - & - & - & - & - & 0,00 & 0,00 \\
\hline Maluku Utara & - & - & - & - & - & - & - & - & - & - & - & - & 0,00 & 0,00 \\
\hline Papua & - & - & - & 0,8 & - & 0,8 & - & - & - & - & - & - & 1,50 & 12,50 \\
\hline Papua Barat & - & - & - & - & - & - & - & - & - & - & - & - & 0,00 & 0,00 \\
\hline Rerata & 0,23 & 0,13 & 1 & 0,26 & 0,14 & 0,22 & 0,29 & 0,22 & 0,11 & 0,13 & 0,19 & 0,3 & 2,324 & 19,363 \\
\hline
\end{tabular}

Sumber: Data primer diolah, 2021

Tabel 2 menunjukkan indeks TPAD tahun 2017. Pada tabel tersebut, tercatat bahwa indeks TPAD tertinggi diraih oleh Pemprov Sumatera Barat dan Pemprov Riau. Kemudian, indeks TPAD terendah dipegang oleh Pemprov Sumatera Utara, Bengkulu, DI Yogyakarta, Sulawesi Utara, Kepulauan Riau, Sulawesi Selatan, Bali, Maluku, Maluku Utara, Gorontalo, Sulawesi Tenggara, Papua Barat, Sulawesi Tengah, dan Sulawesi Barat. Singkatnya, mayoritas pemerintah daerah tidak mempublikasikan informasi pengelolaan anggaran daerah tahun 2017 pada website mereka. Adapun, nilai rata-rata indeks TPAD tahun 2017 adalah 20,65 persen, artinya tingkat TPAD masih terbilang sangat tidak transparan (Adiloglu \& Vuran, 2012).

Bahkan, tabel 2 pula menjelaskan indikator TPAD yang paling banyak dipenuhi pemerintah daerah yaitu informasi Ringkasan DPA-SKPD, dan disusul informasi Peraturan 
Daerah tentang APBD. Sedangkan, indikator TPAD yang paling sedikit dipenuhi oleh pemerintah daerah yaitu informasi tentang LRA-PPKD dan informasi tentang LRA-SKPD. Maknanya, mayoritas pemerintah daerah tidak menyediakan informasi pengelolaan anggaran daerah tentang LRA-SKPD maupun LRA-PPKD pada website mereka.

Tabel 2. Indeks Transparansi Pengelolaan Anggaran (TPAD) Tahun 2017

\begin{tabular}{|c|c|c|c|c|c|c|c|c|c|c|c|c|c|c|}
\hline \multirow{2}{*}{ Nama Pemprov } & \multicolumn{13}{|c|}{ Indikator TPAD Tahun 2017} & \multirow{2}{*}{ Indeks } \\
\hline & 1 & 2 & 3 & 4 & 5 & 6 & 7 & 8 & 9 & 10 & 11 & 12 & Total & \\
\hline Aceh & 0,5 & 0,8 & 0,8 & 0,8 & - & - & 0,5 & - & 0,5 & - & 0,8 & 0,8 & 5,25 & 43,75 \\
\hline Sumatera Utara & - & - & - & - & - & - & - & - & - & - & - & - & 0,00 & 0,00 \\
\hline Sumatera Barat & 0,8 & 0,8 & 0,8 & 0,8 & 0,8 & 0,8 & 0,8 & 0,8 & 0,8 & 0,8 & 0,8 & 0,8 & 9,00 & 75,00 \\
\hline Riau & 0,8 & 0,8 & 0,8 & 0,8 & 0,8 & 0,8 & 1,0 & 1,0 & 0,5 & 0,8 & 0,5 & 0,8 & 9,00 & 75,00 \\
\hline Jambi & 0,8 & - & - & 0,5 & - & - & 0,8 & - & - & 0,8 & 0,5 & 0,8 & 4,00 & 33,33 \\
\hline Sumatera Selatan & - & - & - & 0,5 & - & - & - & - & - & - & 1,0 & - & 1,50 & 12,50 \\
\hline Bengkulu & - & - & - & - & - & - & - & - & - & - & - & - & 0,00 & 0,00 \\
\hline Lampung & - & - & - & 0,5 & - & - & - & - & - & - & - & - & 0,50 & 4,17 \\
\hline Bangka Belitung & 0,8 & 0,8 & - & - & - & 0,8 & 0,8 & - & - & - & - & - & 3,00 & 25,00 \\
\hline Kepulauan Riau & - & - & - & - & - & - & - & - & - & - & - & - & 0,00 & 0,00 \\
\hline Banten & - & - & - & - & - & - & 0,8 & - & - & - & - & - & 0,75 & 6,25 \\
\hline DKI Jakarta & - & - & - & 0,5 & - & 0,8 & - & - & - & - & 1,0 & - & 2,25 & 18,75 \\
\hline Jawa Barat & - & - & 0,8 & 0,8 & 0,8 & - & 1,0 & 1,0 & - & - & 1,0 & 0,5 & 5,75 & 47,92 \\
\hline Jawa Tengah & 0,8 & 0,8 & 1,0 & 1,0 & 0,8 & 0,8 & 0,8 & 0,8 & - & - & - & - & 6,50 & 54,17 \\
\hline DI Yogyakarta & - & - & - & - & - & - & - & - & - & - & - & - & 0,00 & 0,00 \\
\hline Jawa Timur & 0,5 & 0,5 & 0,8 & 1,0 & 0,5 & 0,8 & 0,5 & 0,5 & 0,5 & 0,5 & 0,3 & 0,8 & 7,00 & 58,33 \\
\hline Kalimantan Barat & 1,0 & - & - & - & - & - & - & - & - & - & 0,8 & - & 1,75 & 14,58 \\
\hline Kalimantan Tengah & - & - & 0,8 & 0,8 & 0,8 & 0,8 & 0,8 & - & - & - & - & - & 3,75 & 31,25 \\
\hline Kalimantan Selatan & 0,8 & 0,8 & 0,5 & 1,0 & 1,0 & 1,0 & 1,0 & 1,0 & - & - & 0,8 & 1,0 & 8,75 & 72,92 \\
\hline Kalimantan Timur & 0,8 & 0,8 & - & 0,8 & - & 0,8 & 1,0 & 1,0 & - & - & 0,8 & 0,8 & 6,50 & 54,17 \\
\hline Kalimantan Utara & - & - & - & 0,3 & - & 0,3 & 0,3 & - & - & - & - & - & 0,75 & 6,25 \\
\hline Sulawesi Utara & - & - & - & - & - & - & - & - & - & - & - & - & 0,00 & 0,00 \\
\hline Gorontalo & - & - & - & - & - & - & - & - & - & - & - & - & 0,00 & 0,00 \\
\hline Sulawesi Tengah & - & - & - & - & - & - & - & - & - & - & - & - & 0,00 & 0,00 \\
\hline Sulawesi Selatan & - & - & - & - & - & - & - & - & - & - & - & - & 0,00 & 0,00 \\
\hline Sulawesi Tenggara & - & - & - & - & - & - & - & - & - & - & - & - & 0,00 & 0,00 \\
\hline Sulawesi Barat & - & - & - & - & - & - & - & - & - & - & - & - & 0,00 & 0,00 \\
\hline Bali & - & - & - & - & - & - & - & - & - & - & - & - & 0,00 & 0,00 \\
\hline Nusa Tenggara Barat & - & - & - & - & - & 0,8 & 1,0 & 1,0 & - & 0,5 & - & - & 3,25 & 27,08 \\
\hline Nusa Tenggara Timur & 0,8 & 0,8 & - & 0,8 & - & 0,8 & 0,8 & 0,8 & - & - & - & - & 4,50 & 37,50 \\
\hline Maluku & - & - & - & - & - & - & - & - & - & - & - & - & 0,00 & 0,00 \\
\hline Maluku Utara & - & - & - & - & - & - & - & - & - & - & - & - & 0,00 & 0,00 \\
\hline Papua & - & - & 0,5 & - & - & - & - & - & - & - & - & - & 0,50 & 4,17 \\
\hline Papua Barat & - & - & - & - & - & - & - & - & - & - & - & - & 0,00 & 0,00 \\
\hline Rerata & $0,24^{\top}$ & $0,19^{\prime}$ & $0,19^{\prime}$ & $0,31^{\prime}$ & $0,15^{\prime}$ & $0,26^{\prime}$ & $0,34^{\top}$ & $0,23^{\prime}$ & $0,07^{\top}$ & $0,1^{\prime}$ & $0,24^{\top}$ & 0,18 & 2,478 & 20,65 \\
\hline
\end{tabular}

Sumber: Data primer diolah, 2021

Tabel 3 menginformasikan tentang indeks TPAD Tahun 2018, dari tabel tersebut dapat sampaikan bahwa indeks TPAD tertinggi diraih oleh Pemprov Sumatera Barat. Sementara itu, Pemprov Sulawesi Utara, Kepulauan Riau, Sulawesi Selatan, Maluku Utara, Maluku, Gorontalo, Sulawesi Tenggara, Papua Barat, Sulawesi Tengah, dan Sulawesi Barat. Artinya, terdapat beberapa pemerintah daerah yang tidak mempublikasikan informasi pengelolaan anggaran daerah pada website mereka. Lebih dari itu, berdasarkan nilai ratarata indeks TPAD sebesar 22,67 persen, mengindikasikan bahwa sebagian besar pemerintah daerah tingkat TPAD masih termasuk dalam kualifikasi sangat tidak transparan (Adiloglu \& Vuran, 2012). 
Tabel 3 juga memperlihatkan bahwa pada tahun 2018, indikator TPAD yang paling banyak dipenuhi, yaitu informasi Peraturan Daerah tentang APBD dan informasi tentang LKPD audit. Sementara itu, indikator TPAD yang paling sedikit dipenuhi adalah informasi tentang LRA-PPKD dan LRA-SKPD. Artinya, bahwa informasi pengelolaan anggaran daerah yang berupa LRA-PPKD dan LRA-PPKD, merupakan informasi pengelolaan anggaran daerah yang paling jarang diungkapkan oleh pemerintah daerah pada website mereka.

Tabel 3. Indeks Transparansi Pengelolaan Anggaran (TPAD) Tahun 2018

\begin{tabular}{|c|c|c|c|c|c|c|c|c|c|c|c|c|c|c|}
\hline \multirow{2}{*}{ Nama Pemprov } & \multicolumn{13}{|c|}{ Indikator TPAD Tahun 2018} & \multirow{2}{*}{ Indeks } \\
\hline & 1 & 2 & 3 & 4 & 5 & 6 & 7 & 8 & 9 & 10 & 11 & 12 & Total & \\
\hline Aceh & 0,5 & - & 1,0 & 1,0 & - & - & 0,5 & - & 0,5 & - & 1,0 & - & 4,50 & 37,50 \\
\hline Sumatera Utara & - & - & - & - & 0,3 & - & - & - & - & - & - & - & 0,25 & 2,08 \\
\hline Sumatera Barat & 0,8 & 0,8 & 1,0 & 1,0 & 1,0 & 1,0 & 0,8 & 0,8 & 0,8 & 0,8 & 1,0 & 1,0 & 10,50 & 87,50 \\
\hline Riau & 1,0 & 1,0 & 0,8 & 0,8 & - & - & 1,0 & 1,0 & 0,5 & 1,0 & 0,8 & 0,8 & 8,50 & 70,83 \\
\hline Jambi & 0,8 & - & - & 0,5 & - & - & 0,8 & - & - & - & 0,5 & - & 2,50 & 20,83 \\
\hline Sumatera Selatan & - & - & - & - & - & - & - & - & - & - & 1,0 & 1,0 & 2,00 & 16,67 \\
\hline Bengkulu & - & - & - & - & - & 0,5 & 0,8 & - & 1,0 & - & - & 0,8 & 3,00 & 25,00 \\
\hline Lampung & - & - & - & - & - & 0,5 & - & - & - & - & - & - & 0,50 & 4,17 \\
\hline Bangka Belitung & - & - & - & - & - & 0,8 & - & - & - & - & - & - & 0,75 & 6,25 \\
\hline Kepulauan Riau & - & - & - & - & - & - & - & - & - & - & - & - & 0,00 & 0,00 \\
\hline Banten & 0,8 & 0,8 & 0,8 & 1,0 & 1,0 & 0,8 & - & - & - & - & 0,8 & 0,8 & 6,50 & 54,17 \\
\hline DKI Jakarta & - & - & - & - & - & - & 0,8 & - & - & - & 1,0 & - & 1,75 & 14,58 \\
\hline Jawa Barat & - & - & 0,8 & 1,0 & 0,5 & 0,8 & 1,0 & 1,0 & - & - & 1,0 & 0,8 & 6,75 & 56,25 \\
\hline Jawa Tengah & 0,8 & 0,8 & 1,0 & 1,0 & - & 0,8 & 0,8 & 0,8 & 1,0 & 1,0 & 1,0 & 0,8 & 9,50 & 79,17 \\
\hline DI Yogyakarta & - & - & - & 0,8 & - & 0,8 & - & - & - & - & - & - & 1,50 & 12,50 \\
\hline Jawa Timur & 0,5 & 0,5 & 0,5 & 0,5 & 0,5 & 0,5 & 0,5 & 0,5 & 0,5 & 0,5 & 0,3 & 0,8 & 6,00 & 50,00 \\
\hline Kalimantan Barat & - & - & - & - & - & - & - & - & - & - & 1,0 & - & 1,00 & 8,33 \\
\hline Kalimantan Tengah & 0,8 & 0,8 & 0,8 & 0,8 & 0,8 & 0,8 & 0,8 & 0,8 & - & - & - & - & 6,00 & 50,00 \\
\hline Kalimantan Selatan & 0,8 & 0,8 & 0,5 & 0,8 & 0,8 & 0,8 & 0,8 & 0,8 & - & - & - & - & 5,75 & 47,92 \\
\hline Kalimantan Timur & 0,8 & 0,8 & - & 0,8 & - & - & 1,0 & 1,0 & - & - & 0,8 & - & 5,00 & 41,67 \\
\hline Kalimantan Utara & 0,8 & - & - & 0,5 & 0,5 & 0,5 & - & - & 0,8 & - & 0,5 & 0,5 & 4,00 & 33,33 \\
\hline Sulawesi Utara & - & - & - & - & - & - & - & - & - & - & - & - & 0,00 & 0,00 \\
\hline Gorontalo & - & - & - & - & - & - & - & - & - & - & - & - & 0,00 & 0,00 \\
\hline Sulawesi Tengah & - & - & - & - & - & - & - & - & - & - & - & - & 0,00 & 0,00 \\
\hline Sulawesi Selatan & - & - & - & - & - & - & - & - & - & - & - & - & 0,00 & 0,00 \\
\hline Sulawesi Tenggara & - & - & - & - & - & - & - & - & - & - & - & - & 0,00 & 0,00 \\
\hline Sulawesi Barat & - & - & - & - & - & - & - & - & - & - & - & - & 0,00 & 0,00 \\
\hline Bali & - & 0,8 & - & - & - & - & - & - & - & - & - & - & 0,75 & 6,25 \\
\hline Nusa Tenggara Barat & - & - & 0,5 & - & 0,5 & 0,8 & - & - & 0,3 & 0,5 & - & - & 2,50 & 20,83 \\
\hline Nusa Tenggara Timur & 0,8 & 0,8 & - & 0,8 & - & - & - & - & - & - & - & - & 2,25 & 18,75 \\
\hline Maluku & - & - & - & - & - & - & - & - & - & - & - & - & 0,00 & 0,00 \\
\hline Maluku Utara & - & - & - & - & - & - & - & - & - & - & - & - & 0,00 & 0,00 \\
\hline Papua & - & - & - & 0,8 & - & - & - & - & - & - & - & - & 0,75 & 6,25 \\
\hline Papua Barat & - & - & - & - & - & - & - & - & - & - & - & - & 0,00 & 0,00 \\
\hline Rerata & 0,26 & 0,22 & 0,22 & 0,35 & 0,17 & 0,26 & 0,27 & 0,19 & 0,15 & 0,11 & 0,31 & 0,21 & 2,72 & 22,67 \\
\hline
\end{tabular}

Sumber: Data primer diolah, 2021

Tabel 4 menunjukkan indeks TPAD Tahun 2019, dari tabel tersebut dapat diterangkan bahwa indeks TPAD teratas diduduki oleh Pemprov Jawa Tengah dan Pemprov Kalimantan Selatan. Kemudian, indeks TPAD terbawah ditempati oleh Pemprov Sulawesi Tengah, Jawa Barat, Sulawesi Selatan, Bangka Belitung, Maluku Utara, Gorontalo, dan Papua Barat. Artinya, terdapat beberapa pemerintah daerah sama sekali tidak mempublikasikan informasi pengelolaan anggaran daerah tahun 2019 pada website mereka. Selain itu, secara 
rata-rata nilai indeks TPAD sebesar 29,96 persen, artinya tingkat TPAD pemerintah daerah pada tahun 2019 masih tergolong sangat tidak transparan (Adiloglu \& Vuran, 2012).

Tabel 4 juga menggambarkan bahwa pada tahun 2019 indikator TPAD paling banyak dipenuhi oleh pemerintah daerah pada website mereka adalah informasi Perda tentang APBD dan informasi tentang Ringkasan DPA-SKPD. Sementara itu, indikator TPAD yang paling sedikit dipenuhi pada website pemerintah daerah adalah informasi Raperda tentang Perubahan APBD dan LRA-PPKD. Artinya, pada tahun 2019 hanya beberapa pemerintah daerah yang mempublikasikan informasi pengelolaan anggaran daerah berupa Raperda tentang Perubahan APBD dan LRA-PPKD pada website mereka.

Tabel 4. Indeks Transparansi Pengelolaan Anggaran (TPAD) Tahun 2019

\begin{tabular}{|c|c|c|c|c|c|c|c|c|c|c|c|c|c|c|}
\hline \multirow{2}{*}{ Nama Pemprov } & \multicolumn{13}{|c|}{ Indikator TPAD Tahun 2019} & \multirow{2}{*}{ Indeks } \\
\hline & 1 & 2 & 3 & 4 & 5 & 6 & 7 & 8 & 9 & 10 & 11 & 12 & Total & \\
\hline Aceh & 0,5 & - & - & 1,0 & - & 1,0 & - & 0,8 & 0,5 & - & 1,0 & - & 4,75 & 39,58 \\
\hline Sumatera Utara & - & - & - & - & - & 0,3 & 0,8 & - & - & - & - & - & 1,00 & 8,33 \\
\hline Sumatera Barat & 0,8 & 0,8 & 1,0 & 1,0 & 0,8 & 0,8 & 0,8 & 0,8 & 0,8 & 0,8 & 0,8 & 0,8 & 9,50 & 79,17 \\
\hline Riau & 1,0 & 1,0 & 0,8 & 0,8 & 0,8 & 1,0 & 1,0 & 1,0 & 0,5 & 0,8 & 0,8 & 0,8 & 10,00 & 83,33 \\
\hline Jambi & 1,0 & - & - & 0,5 & - & - & 1,0 & - & - & - & 0,5 & - & 3,00 & 25,00 \\
\hline Sumatera Selatan & - & - & - & - & - & - & - & - & - & - & - & - & 0,00 & 0,00 \\
\hline Bengkulu & - & - & - & 0,8 & - & - & 1,0 & 0,8 & 1,0 & 1,0 & - & - & 4,50 & 37,50 \\
\hline Lampung & - & - & - & 0,5 & - & 0,5 & - & - & - & - & - & - & 1,00 & 8,33 \\
\hline Bangka Belitung & - & - & - & - & - & 1,0 & 0,8 & - & - & - & - & - & 1,75 & 14,58 \\
\hline Kepulauan Riau & - & - & - & 0,5 & - & 0,8 & - & - & 0,8 & - & - & - & 2,00 & 16,67 \\
\hline Banten & 0,8 & 0,8 & 1,0 & 1,0 & - & - & - & - & - & - & 1,0 & 1,0 & 5,50 & 45,83 \\
\hline DKI Jakarta & - & - & - & 0,8 & - & 0,8 & 0,8 & - & - & - & 1,0 & - & 3,25 & 27,08 \\
\hline Jawa Barat & - & - & - & 0,8 & - & - & 1,0 & 1,0 & - & - & 1,0 & - & 3,75 & 31,25 \\
\hline Jawa Tengah & 0,8 & 0,8 & 0,8 & 1,0 & 0,8 & 1,0 & 0,8 & 0,8 & 1,0 & 1,0 & 1,0 & 1,0 & 10,50 & 87,50 \\
\hline DI Yogyakarta & - & - & - & 0,8 & 0,5 & 0,5 & - & - & - & - & - & - & 1,75 & 14,58 \\
\hline Jawa Timur & 0,5 & 0,5 & 0,8 & 0,8 & 0,8 & 0,8 & 0,5 & 0,5 & 0,5 & 0,5 & 0,3 & 0,8 & 7,00 & 58,33 \\
\hline Kalimantan Barat & 1,0 & - & - & 0,5 & - & - & 1,0 & - & - & - & 1,0 & - & 3,50 & 29,17 \\
\hline Kalimantan Tengah & 0,8 & - & 0,8 & 0,8 & 0,8 & 0,8 & - & 0,5 & - & - & - & - & 4,25 & 35,42 \\
\hline Kalimantan Selatan & 1,0 & 1,0 & 0,3 & 1,0 & 0,3 & 1,0 & 1,0 & 1,0 & 1,0 & 1,0 & 1,0 & 1,0 & 10,50 & 87,50 \\
\hline Kalimantan Timur & 0,8 & - & - & - & - & - & 1,0 & - & - & - & 0,8 & - & 2,50 & 20,83 \\
\hline Kalimantan Utara & 0,8 & 0,8 & 0,5 & 0,5 & 0,5 & 0,5 & 0,8 & 0,8 & 1,0 & 1,0 & 1,0 & 1,0 & 9,00 & 75,00 \\
\hline Sulawesi Utara & - & 0,5 & - & 0,5 & - & - & - & - & - & - & - & 0,5 & 1,50 & 12,50 \\
\hline Gorontalo & - & - & - & - & - & - & - & - & - & - & - & - & 0,00 & 0,00 \\
\hline Sulawesi Tengah & - & - & - & - & - & - & - & - & - & - & - & - & 0,00 & 0,00 \\
\hline Sulawesi Selatan & - & - & - & - & - & - & - & - & - & - & - & - & 0,00 & 0,00 \\
\hline Sulawesi Tenggara & - & - & - & - & - & - & - & - & - & - & - & - & 0,00 & 0,00 \\
\hline Sulawesi Barat & 0,8 & - & - & 0,8 & - & - & 0,8 & - & - & - & - & - & 2,25 & 18,75 \\
\hline Bali & 0,8 & 0,8 & 0,5 & 0,5 & 0,5 & 0,5 & 0,8 & 0,8 & - & - & 1,0 & 1,0 & 7,00 & 58,33 \\
\hline Nusa Tenggara Barat & 0,8 & - & 0,8 & 0,8 & 0,8 & 0,5 & 1,0 & 1,0 & 0,8 & - & 1,0 & - & 7,25 & 60,42 \\
\hline Nusa Tenggara Timur & 0,8 & 0,8 & - & - & - & 0,8 & 0,8 & 0,8 & - & - & - & - & 3,75 & 31,25 \\
\hline Maluku & - & - & - & - & - & - & - & - & - & - & - & - & 0,00 & 0,00 \\
\hline Maluku Utara & - & - & - & - & - & - & - & - & - & - & - & - & 0,00 & 0,00 \\
\hline Papua & - & - & - & 0,8 & - & 0,8 & - & - & - & - & - & - & 1,50 & 12,50 \\
\hline Papua Barat & - & - & - & - & - & - & - & - & - & - & - & - & 0,00 & 0,00 \\
\hline Rerata & $0,37^{\top}$ & 0,22 & $0,21^{\prime}$ & $0,4^{\prime}$ & $0,18^{\prime}$ & $0,38^{\prime}$ & $0,45^{\prime}$ & 0,3 & $0,23^{\prime}$ & $0,18^{\prime}$ & $0,38^{\prime \prime}$ & 0,23 & 3,596 & 29,96 \\
\hline
\end{tabular}

Sumber: Data primer diolah, 2021

Kemudian, Tabel 5 menyampaikan gambaran tentang indeks TPAD Tahun 2020, berdasarkan pada tabel tersebut, ditemukan bahwa indeks TPAD yang berada pada posisi paling atas adalah Pemprov Riau. Sementara itu, indeks TPAD yang berada pada posisi paling bawah, yaitu Pemprov Sulawesi Tengah, Jawa Barat, Sulawesi Selatan, Maluku Utara, Bangka Belitung, Gorontalo, dan Papua Barat. Artinya, masih banyak pemerintah daerah 
yang tidak mempublikasikan informasi pengelolaan anggaran daerah tahun 2020 pada website mereka. Lebih dari itu, berdasarkan nilai rata-rata indeks TPAD sebesar 28,55 persen, artinya secara keseluruhan pemerintah daerah dalam pengelolaan anggaran daerah tergolong dalam kualifikasi sangat tidak transparan (Adiloglu \& Vuran, 2012).

Selanjutnya, tabel 5 pun memperlihatkan indikator TPAD yang lebih banyak dipenuhi oleh pemerintah daerah pada tahun 2020 adalah informasi Peraturan Daerah tentang APBD. Sementara itu, indikator TPAD yang paling kurang dipenuhi oleh pemerintah daerah adalah informasi tentang RKA-PPKD dan informasi tentang LRA-SKPD dan LRA-PPKD. Intinya, mayoritas pemerintah daerah pada tahun 2020 belum menyajikan informasi pengelolaan anggaran daerah yang memuat tentang RKA-PPKD, begitupula informasi tentang LRA-SKPD dan LRA-PPKD pada website mereka.

Tabel 5. Indeks Transparansi Pengelolaan Anggaran (TPAD) Tahun 2020

\begin{tabular}{|c|c|c|c|c|c|c|c|c|c|c|c|c|c|c|}
\hline \multirow{2}{*}{ Nama Pemprov } & \multicolumn{13}{|c|}{ Indikator TPAD Tahun 2020} & \multirow{2}{*}{ Indeks } \\
\hline & 1 & 2 & 3 & 4 & 5 & 6 & 7 & 8 & 9 & 10 & 11 & 12 & Total & \\
\hline Aceh & 0,8 & - & - & 1,0 & - & 0,8 & - & - & - & - & - & - & 2,50 & 20,83 \\
\hline Sumatera Utara & - & - & - & 0,3 & - & - & - & - & - & - & - & - & 0,25 & 2,08 \\
\hline Sumatera Barat & 0,8 & 0,8 & 1,0 & 1,0 & 1,0 & 0,8 & 0,8 & 0,8 & 0,8 & 0,8 & 1,0 & 1,0 & 10,25 & 85,42 \\
\hline Riau & 1,0 & 1,0 & 0,8 & 1,0 & 0,8 & 1,0 & 1,0 & 1,0 & 0,8 & 0,8 & 1,0 & 1,0 & 11,00 & 91,67 \\
\hline Jambi & 1,0 & 0,8 & 0,5 & 0,5 & 0,5 & 0,5 & 0,8 & 0,8 & 0,8 & - & 0,5 & 0,8 & 7,25 & 60,42 \\
\hline Sumatera Selatan & - & - & - & 0,5 & - & - & - & - & - & - & 0,8 & - & 1,25 & 10,42 \\
\hline Bengkulu & - & - & - & 1,0 & - & 1,0 & - & - & - & 1,0 & - & - & 3,00 & 25,00 \\
\hline Lampung & - & - & - & 0,5 & 0,5 & - & - & - & - & - & - & - & 1,00 & 8,33 \\
\hline Bangka Belitung & - & - & - & - & - & - & - & - & - & - & - & - & 0,00 & 0,00 \\
\hline Kepulauan Riau & - & - & - & 0,8 & - & - & - & - & - & - & 1,0 & 1,0 & 2,75 & 22,92 \\
\hline Banten & 0,8 & - & - & - & - & 1,0 & - & - & - & - & 1,0 & 1,0 & 3,75 & 31,25 \\
\hline DKI Jakarta & - & - & - & - & - & - & - & - & 1,0 & 1,0 & 1,0 & 1,0 & 4,00 & 33,33 \\
\hline Jawa Barat & - & - & - & - & - & - & - & - & - & - & - & - & 0,00 & 0,00 \\
\hline Jawa Tengah & 0,8 & 0,8 & 0,8 & 1,0 & 1,0 & 1,0 & 1,0 & 1,0 & - & - & 0,8 & - & 8,00 & 66,67 \\
\hline DI Yogyakarta & - & - & - & 0,8 & - & 0,8 & - & - & 0,8 & 0,8 & - & - & 3,00 & 25,00 \\
\hline Jawa Timur & 0,5 & 0,5 & 0,8 & 0,8 & 0,8 & 0,8 & 0,5 & 0,5 & 0,5 & 0,5 & 0,3 & 0,8 & 7,00 & 58,33 \\
\hline Kalimantan Barat & - & - & 1,0 & 0,8 & - & - & - & - & - & - & 0,8 & 1,0 & 3,50 & 29,17 \\
\hline Kalimantan Tengah & - & - & 1,0 & 0,8 & - & - & 1,0 & 1,0 & - & - & - & - & 3,75 & 31,25 \\
\hline Kalimantan Selatan & 0,8 & - & - & 1,0 & - & 1,0 & 1,0 & 1,0 & 0,8 & 0,8 & 0,8 & 0,8 & 7,75 & 64,58 \\
\hline Kalimantan Timur & 1,0 & - & - & - & - & 0,5 & 1,0 & - & - & - & 1,0 & - & 3,50 & 29,17 \\
\hline Kalimantan Utara & 0,8 & 0,8 & 0,5 & 0,5 & 0,5 & 0,5 & 1,0 & 1,0 & 0,8 & 0,8 & 0,8 & 0,8 & 8,50 & 70,83 \\
\hline Sulawesi Utara & 0,5 & - & - & 0,8 & 1,0 & 0,5 & 0,8 & - & - & - & 0,5 & - & 4,00 & 33,33 \\
\hline Gorontalo & - & - & - & - & - & - & - & - & - & - & - & - & 0,00 & 0,00 \\
\hline Sulawesi Tengah & - & - & - & - & - & - & - & - & - & - & - & - & 0,00 & 0,00 \\
\hline Sulawesi Selatan & - & - & - & - & - & - & - & - & - & - & - & - & 0,00 & 0,00 \\
\hline Sulawesi Tenggara & - & - & - & - & - & - & - & 1,0 & - & - & - & - & 1,00 & 8,33 \\
\hline Sulawesi Barat & - & - & - & - & 0,8 & - & - & - & - & - & - & - & 0,75 & 6,25 \\
\hline Bali & 0,8 & 0,8 & 0,5 & 0,5 & 0,5 & 0,5 & - & 0,8 & - & - & - & - & 4,25 & 35,42 \\
\hline Nusa Tenggara Barat & 1,0 & - & 0,8 & 0,8 & 0,8 & 0,8 & 1,0 & 1,0 & - & - & 1,0 & 1,0 & 8,00 & 66,67 \\
\hline Nusa Tenggara Timur & 0,8 & - & - & 1,0 & - & - & 1,0 & 1,0 & - & - & - & - & 3,75 & 31,25 \\
\hline Maluku & - & - & - & 0,3 & - & - & - & - & - & - & 0,5 & 0,5 & 1,25 & 10,42 \\
\hline Maluku Utara & - & - & - & - & - & - & - & - & - & - & - & - & 0,00 & 0,00 \\
\hline Papua & - & - & - & 0,8 & 0,8 & - & - & - & - & - & - & - & 1,50 & 12,50 \\
\hline Papua Barat & - & - & - & - & - & - & - & - & - & - & - & - & 0,00 & 0,00 \\
\hline Rerata & 0,32 & $0,15^{\prime}$ & 0,22 & 0,47 & 0,26 & $0,33^{\prime}$ & 0,32 & 0,32 & 0,18 & $0,18^{\prime}$ & 0,37 & 0,31 & 3,426 & 28,55 \\
\hline
\end{tabular}

Sumber: Data primer diolah, 2021

Selanjutnya, Tabel 6 menunjukkan perkembangan indeks TPAD Tahun 2016 - 2020. Melalui tabel itu, diketahui bahwa pemerintah daerah yang memperoleh nilai rata-rata 
indeks TPAD tertinggi selama lima tahun adalah Pemprov Sumatera Barat. Sementara itu, Pemprov Sulawesi Tengah, Sulawesi Selatan, Gorontalo, Maluku Utara, dan Papua Barat selama lima tahun berturut-turut tidak mempublikasikan informasi pengelolaan anggaran daerah pada website mereka. Selain itu, informasi dari tabel tersebut juga mengindikasikan bahwa secara rata-rata indeks TPAD pemerintah daerah terus mengalami peningkatan dari tahun-tahun sebelumnya. Kemudian, rata-rata indeks TPAD selama lima tahun terakhir sebesar 24,24 persen. Angka ini mengindikasikan bahwa tingkat TPAD masih termasuk dalam kualifikasi sangat tidak transparan (Adiloglu \& Vuran, 2012).

Tabel 6. Perkembangan Indeks Transparansi Pengelolaan Anggaran (TPAD)

\begin{tabular}{|c|c|c|c|c|c|c|}
\hline \multirow{2}{*}{ Nama Pemprov } & \multicolumn{5}{|c|}{ Tahun } & \multirow{2}{*}{ Rerata } \\
\hline & 2016 & 2017 & 2018 & 2019 & 2020 & \\
\hline Aceh & 20,83 & 33,33 & 37,50 & 41,67 & 25,00 & 31,67 \\
\hline Sumatera Utara & 0,00 & 0,00 & 2,08 & 10,42 & 2,08 & 2,92 \\
\hline Sumatera Barat & 50,00 & 50,00 & 75,00 & 58,33 & 70,83 & 60,83 \\
\hline Riau & 75,00 & 75,00 & 70,83 & 83,33 & 95,83 & 80,00 \\
\hline Jambi & 25,00 & 25,00 & 16,67 & 25,00 & 50,00 & 28,33 \\
\hline Sumatera Selatan & 4,17 & 12,50 & 16,67 & 0,00 & 8,33 & 8,33 \\
\hline Bengkulu & 0,00 & 0,00 & 20,83 & 41,67 & 25,00 & 17,50 \\
\hline Lampung & 12,50 & 4,17 & 4,17 & 8,33 & 8,33 & 7,50 \\
\hline Bangka Belitung & 25,00 & 16,67 & 4,17 & 16,67 & 0,00 & 12,50 \\
\hline Kepulauan Riau & 0,00 & 0,00 & 0,00 & 16,67 & 25,00 & 8,33 \\
\hline Banten & 0,00 & 4,17 & 41,67 & 41,67 & 29,17 & 23,33 \\
\hline DKI Jakarta & 8,33 & 20,83 & 16,67 & 33,33 & 33,33 & 22,50 \\
\hline Jawa Barat & 54,17 & 50,00 & 58,33 & 33,33 & 0,00 & 39,17 \\
\hline Jawa Tengah & 37,50 & 41,67 & 66,67 & 75,00 & 58,33 & 55,83 \\
\hline DI Yogyakarta & 0,00 & 0,00 & 8,33 & 16,67 & 16,67 & 8,33 \\
\hline Jawa Timur & 56,25 & 47,92 & 35,42 & 52,08 & 52,08 & 48,75 \\
\hline Kalimantan Barat & 25,00 & 16,67 & 8,33 & 29,17 & 33,33 & 22,50 \\
\hline Kalimantan Tengah & 0,00 & 20,83 & 33,33 & 25,00 & 33,33 & 22,50 \\
\hline Kalimantan Selatan & 45,83 & 70,83 & 33,33 & 83,33 & 54,17 & 57,50 \\
\hline Kalimantan Timur & 66,67 & 50,00 & 37,50 & 16,67 & 29,17 & 40,00 \\
\hline Kalimantan Utara & 0,00 & 6,25 & 29,17 & 66,67 & 58,33 & 32,08 \\
\hline Sulawesi Utara & 0,00 & 0,00 & 0,00 & 10,42 & 31,25 & 8,33 \\
\hline Gorontalo & 0,00 & 0,00 & 0,00 & 0,00 & 0,00 & 0,00 \\
\hline Sulawesi Tengah & 0,00 & 0,00 & 0,00 & 0,00 & 0,00 & 0,00 \\
\hline Sulawesi Selatan & 0,00 & 0,00 & 0,00 & 0,00 & 0,00 & 0,00 \\
\hline Sulawesi Tenggara & 0,00 & 0,00 & 0,00 & 0,00 & 8,33 & 1,67 \\
\hline Sulawesi Barat & 0,00 & 0,00 & 0,00 & 20,83 & 8,33 & 5,83 \\
\hline Bali & 0,00 & 0,00 & 4,17 & 50,00 & 29,17 & 16,67 \\
\hline Nusa Tenggara Barat & 12,50 & 29,17 & 22,92 & 70,83 & 75,00 & 42,08 \\
\hline Nusa Tenggara Timur & 25,00 & 25,00 & 12,50 & 20,83 & 29,17 & 22,50 \\
\hline Maluku & 0,00 & 0,00 & 0,00 & 0,00 & 6,25 & 1,25 \\
\hline Maluku Utara & 0,00 & 0,00 & 0,00 & 0,00 & 0,00 & 0,00 \\
\hline Papua & 16,67 & 4,17 & 8,33 & 16,67 & 16,67 & 12,50 \\
\hline Papua Barat & 0,00 & 0,00 & 0,00 & 0,00 & 0,00 & 0,00 \\
\hline Rerata & 19,36 & 20,65 & 22,67 & 29,96 & 28,55 & 24,24 \\
\hline
\end{tabular}

Sumber: Data primer diolah, 2021

Merujuk pada Gambar 1, dapat dijelaskan tingkat kualifikasi TPAD berdasarkan kategori keterbukaan anggaran yang ditetapkan oleh IBP (2019) bahwa Pemprov Sumatera Barat sebagai satu-satunya pemerintah daerah yang tergolong dalam kriteria ekstensif. Terdapat tiga pemerintah daerah yang termuat dalam kelompok substansial, yaitu 
Pemprov Riau, Kalimantan Selatan, dan Jawa Tengah. Kemudian, Pemprov Jawa Timur dan Kalimantan Timur terhitung dalam kualifikasi terbatas. Terdapat 10 pemerintah daerah termasuk dalam kualifikasi minimal, yaitu Pemprov Nusa Tenggara Barat, Jawa Barat, Kalimantan Utara, Jambi, Aceh, Nusa Tenggara Timur, Kalimantan Tengah, Banten, Kalimantan Barat, dan DKI Jakarta. Lebihnya, sebanyak 18 pemerintah daerah terbilang dalam urutan sedikit, yaitu pemprov Bali, Bengkulu, Bangka Belitung, DI Yogyakarta, Papua, Sumatera Selatan, Sulawesi Utara, Kepulauan Riau, Lampung, Sulawesi Barat, Sumatera Utara, Maluku, Sulawesi Tenggara, Sulawesi Tengah, Sulawesi Selatan, Maluku Utara, Gorontalo, Papua Barat. Maknanya, sebagian besar pemerintah daerah di Indonesia masih termuat dalam derajat keterbukaan informasi yang tidak cukup (insufficient) (IBP, 2019).

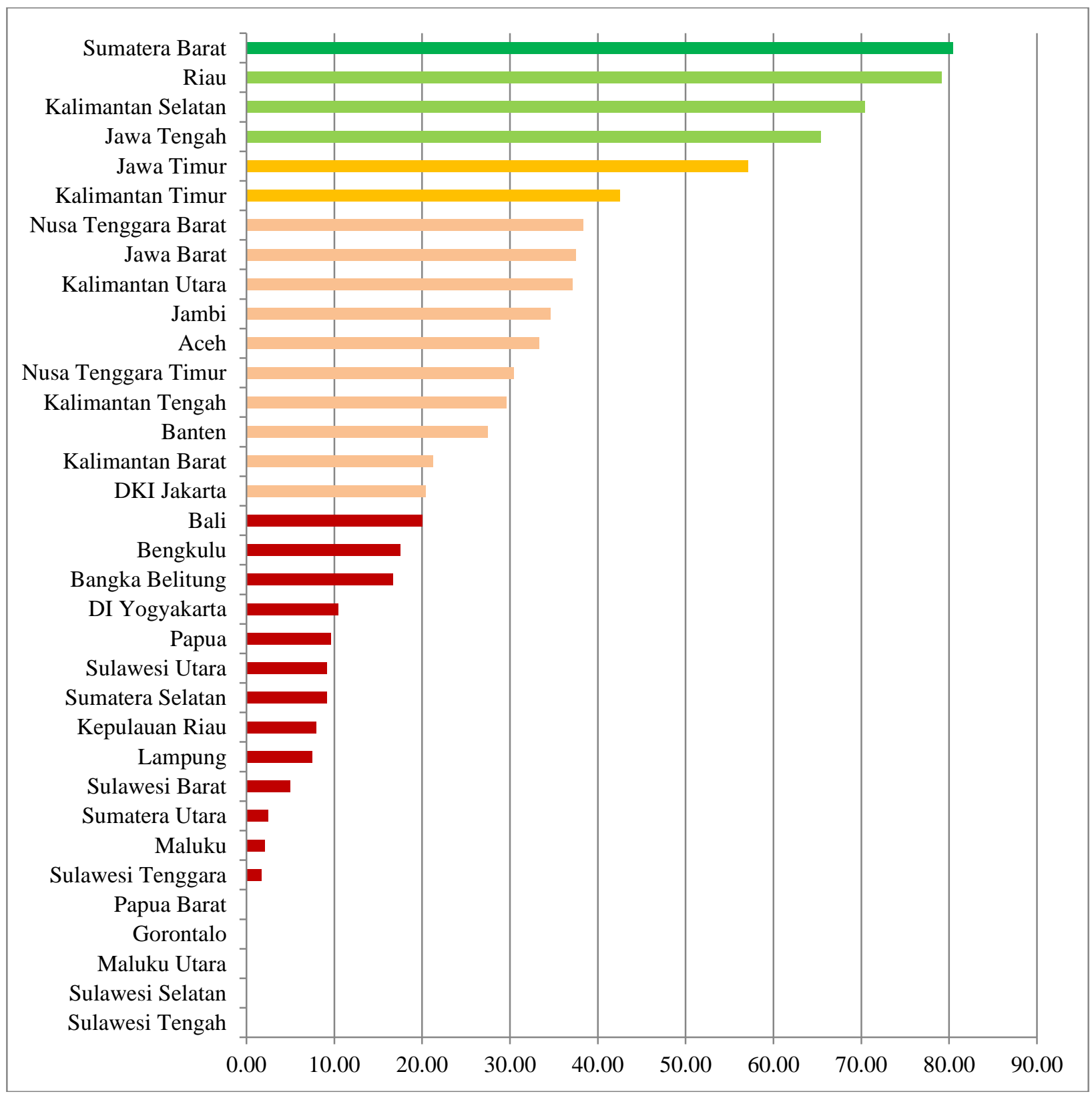

Gambar 1. Indeks Transparansi Pengelolaan Anggaran Daerah (TPAD)

Sederhananya, temuan penelitian ini sejalan dengan hasil penelitian Alwahidi and Darwanis (2019); Nuryani and Firmansyah (2020); Adriana and Ritonga (2018); Syamsul and Ritonga (2017); Syamsul (2020) yang menginformasikan bahwa rata-rata tingkat 
TPAD di Indonesia masih sangat rendah, kurang dari 50,00 persen. Artinya, pengelolaan anggaran daerah masih sangat tidak transparan. Selain itu, temuan ini mengindikasikan bahwa tingkat kepatuhan pemerintah daerah terhadap regulasi yang ada. Khususnya, regulasi yang mengatur tentang keharusan pemerintah daerah mempublikasi informasi mutahir tentang pengelolaan anggaran daerah pada website pemerintah daerah (Syamsul, 2020). Bahkan, temuan ini juga menginformasikan bahwa masih terdapat beberapa pemerintah daerah yang belum menyadari pentingnya atau belum maksimal dalam menfaatkan website pemerintah daerah sebagai media dalam mewujudkan prinsip transaparansi dan akuntabilitas pengelolaan anggaran daerah (Agustin, 2014; Putra, et.al., 2018). Padahal, e-government yang berbentuk website pemerintah daerah adalah media yang lebih efisien dan efektif dalam pengungkapan informasi publik.

Tabel 7. Perbandingan Indeks Transparansi Pengelolaan Anggaran (TPAD)

Tanpa Kriteria Kelengkapan dan Dengan Kriteria Kelengkapan 


\begin{tabular}{|c|c|c|c|c|}
\hline Peringkat & $\begin{array}{c}\text { Nama } \\
\text { Pemprov }\end{array}$ & $\begin{array}{c}\text { Tanpa } \\
\text { Kelengkapan }\end{array}$ & $\begin{array}{c}\text { Nama } \\
\text { Pemprov }\end{array}$ & $\begin{array}{c}\text { Dengan } \\
\text { Kel engkapan }\end{array}$ \\
\hline 1 & Riau & 80,00 & Sumatera Barat & 80,42 \\
\hline 2 & Sumatera Barat & 60,83 & Riau & 79,17 \\
\hline 3 & Kalimantan Selatan & 57,50 & Kalimantan Selatan & 70,42 \\
\hline 4 & Jawa Tengah & 55,83 & Jawa Tengah & 65,42 \\
\hline 5 & Jawa Timur & 48,75 & Jawa Timur & 57,08 \\
\hline 6 & Nusa Tenggara Barat & 42,08 & Kalimantan Timur & 42,50 \\
\hline 7 & Kalimantan Timur & 40,00 & Nusa Tenggara Barat & 38,33 \\
\hline 8 & Jawa Barat & 39,17 & Jawa Barat & 37,50 \\
\hline 9 & Kalimantan Utara & 32,08 & Kalimantan Utara & 37,08 \\
\hline 10 & Aceh & 31,67 & Jambi & 34,58 \\
\hline 11 & Jambi & 28,33 & Aceh & 33,33 \\
\hline 12 & Banten & 23,33 & Nusa Tenggara Timur & 30,42 \\
\hline 13 & Nusa Tenggara Timur & 22,50 & Kalimantan Tengah & 29,58 \\
\hline 14 & Kalimantan Barat & 22,50 & Banten & 27,50 \\
\hline 15 & DKI Jakarta & 22,50 & Kalimantan Barat & 21,25 \\
\hline 16 & Kalimantan Tengah & 22,50 & DKI Jakarta & 20,42 \\
\hline 17 & Bengkulu & 17,50 & Bali & 20,00 \\
\hline 18 & Bali & 16,67 & Bengkulu & 17,50 \\
\hline 19 & Papua & 12,50 & Bangka Belitung & 16,67 \\
\hline 20 & Bangka Belitung & 12,50 & DI Yogyakarta & 10,42 \\
\hline 21 & Sulawesi Utara & 8,33 & Papua & 9,58 \\
\hline 22 & Sumatera Selatan & 8,33 & Sumatera Selatan & 9,17 \\
\hline 23 & DI Yogyakarta & 8,33 & Sulawesi Utara & 9,17 \\
\hline 24 & Kepulauan Riau & 8,33 & Kepulauan Riau & 7,92 \\
\hline 25 & Lampung & 7,50 & Lampung & 7,50 \\
\hline 26 & Sulawesi Barat & 5,83 & Sulawesi Barat & 5,00 \\
\hline 27 & Sumatera Utara & 2,92 & Sumatera Utara & 2,50 \\
\hline 28 & Sulawesi Tenggara & 1,67 & Maluku & 2,08 \\
\hline 29 & Maluku & 1,25 & Sulawesi Tenggara & 1,67 \\
\hline 30 & Sulawesi Tengah & 0,00 & Sulawesi Tengah & 0,00 \\
\hline 31 & Sulawesi Selatan & 0,00 & Sulawesi Selatan & 0,00 \\
\hline 32 & Maluku Utara & 0,00 & Maluku Utara & 0,00 \\
\hline 33 & Gorontalo & 0,00 & Gorontalo & 0,00 \\
\hline \multirow[t]{2}{*}{34} & Papua Barat & 0,00 & Papua Barat & 0,00 \\
\hline & Rata-rata & 21,80 & Rata-rata & 24,24 \\
\hline
\end{tabular}

Sumber: Data primer diolah, 2021

Indeks TPAD pada penelitian ini dinilai berdasarkan rekomendasi dari (Syamsul, 2020), yaitu dengan menambahkan satu kriteria informasi yaitu kelengkapan informasi yang dipublikasikan. Pada tabel 7 terlihat perbedaan antara indeks TPAD yang tidak menggunakan kriteria kelengkapan dan dengan kriteria kelengkapan informasi. Dari tabel tersebut terlihat bahwa indeks TPAD tertinggi tanpa menggunakan kriteria kelengkapan informasi adalah sebesar 80,00 persen diraih oleh Pemprov Riau. Sementara itu, dengan menggunakan kriteria kelengkapan informasi, diperoleh nilai indeks TPAD tertinggi sebesar 80,42 persen diduduki oleh Pemprov Sumatera Barat. Selain itu, secara rata-rata indeks TPAD tanpa kriteria kelengkapan informasi sebesar 21,80 persen, kemudian nilai 
rata-rata indeks TPAD dengan menggunakan kriteria kelengkapan informasi sebesar 24,24 persen. Maknanya, terdapat perbedaan antara nilai indeks TPAD tanpa menggunakan kriteria kelengkapan informasi dan dengan menetapkan kriteria kelengkapan informasi dalam menilai indikator TPAD. Oleh karena itu, penelitian ini menguatkan argumentasi dari Syamsul (2020) bahwa memasukkan kriteria kelengkapan dalam menilai indikator TPAD itu penting untuk dilakukan. Tujuannya adalah untuk memastikan kebermanfaatan sebuah informasi yang disajikan oleh pemerintah daerah pada website mereka. Artinya, percuma tersedia, dapat diakses, disajikan tepat waktu, tetapi tidak lengkap. Singkatya, apabila informasi yang disajikan itu tidak lengkap tentu tidak dapat dijadikan rujukan dalam penetapan kebijakan, sebutan lainnya informasi yang tidak lengkap dapat menyesatkan para pengambil keputusan

\section{SIMPULAN}

Penelitian ini menginformasikan bahwa peringkat tertinggi indeks TPAD diraih oleh Pemprov Sumatera Barat, diikuti oleh Pemprov Riau sebagai peringkat kedua, dan Pemprov Kalimantan Selatan sebagai peringkat ketiga. Kemudian, terdapat lima pemerintah daerah yang tidak mempublikasikan satupun indikator TPAD pada website mereka, yaitu Pemprov Sulawesi Barat, Sulawesi Selatan, Gorontalo, Maluku Utara, dan Papua Barat. Singkatnya, secara keseluruhan tingkat TPAD masih tergolong sangat tidak transparan atau dengan kata lain tingkat keterbukaan anggaran pemerintah daerah masih termasuk dalam kualifikasi tidak cukup (insufficient). Meskipun demikian, penelitian ini juga berhasil menginformasikan bahwa indeks TPAD terus mengalami peningkatan secara positif dari tahun-tahun sebelumnya. Lebih dari itu, penelitian ini juga berhasil membuktikan bahwa dengan menggunakan kriteria kelengkapan dalam menilai indeks TPAD yang disajikan melalui website pemerintah daerah menjadikan pengukuran lebih akurat.

Penelitian ini memiliki kelemahan dalam menilai kriteria ketepatan waktu informasi. Keterbatasan ini terjadi karena tidak semua pemerintah daerah menuliskan waktu pengungkapan informasi pengelolaan anggaran daerah pada website mereka. Begitupula pada file dokumen yang dipublikasikan, sebagian pemerintah daerah tidak mengaktifkan tanggal pembuatan dan pengeditan terakhir, sehingga sulit untuk mengindentifikasi tanggal unggah dari sebuah dokumen. Dengan demikian, terdapat beberapa file yang dinyatakan tidak tepat waktu karena tidak diketahui kapan file tersebut disebarluaskan. Selain itu, pada saat pengambilan data terdapat beberapa link yang tidak bisa diakses, karena dalam masa perbaikan (maintenance) sehingga informasi pengelolaan anggaran daerah pada link tersebut tidak ditemukan. Penelitian selanjutnya, dapat mengeksplorasi faktor-faktor penentu utama TPAD pada website pemerintah daerah melalui wawancara mendalam (deep interview), sehingga dapat diketahui lebih dalam faktor pendukung dan penghambat publikasi melalui internet.

\section{UCAPAN TERIMAKASIH}

Terima kasih kepada Kementerian Pendidikan, Kebudayaan, Riset, dan teknologi Republik Indonesia sebagai penyandang dana penelitian.

\section{DAFTAR PUSTAKA}

Adiloglu \& Vuran. (2012). The Relationship Between The Financial Ratios And Transparency Levels Of Financial Information Disclosures Within The Scope Of Corporate Governance : Evidence From Turkey. In The Journal of Applied Business Research (Vol. 28, Issue 4, pp. 543-554).

Adriana, A., \& Ritonga, I. T. (2018). Analysis of Local Financial Management Transparency Based on Websites on Local Government in Java. Jurnal Dinamika Akuntansi, 10(1), 13-26. 
https://doi.org/10.15294/jda.v10i1.12558

Agustin, H. (2014). Publikasi Dokumen Pengelolaan Anggaran pada Website Pemkab / Pemkot di Propinsi Sumatera Barat. Seminar Nasional Aplikasi Teknologi Informasi (SNATI), 7-12.

Alwahidi, M. R., \& Darwanis, D. (2019). Pengukuran Transparansi Keuangan Daerah Berbasis Website Pada Kabupaten/Kota Di Indonesia. Jurnal Ilmiah Mahasiswa Ekonomi Akuntansi, 4(1), 153. https://doi.org/10.24815/jimeka.v4i1.10806

Esteves de Araujo, J. F. F., \& Tejedo-Romero, F. (2016). Local government transparency index: determinants of municipalities' rankings. https://doi.org/10.1108/IJEBR-02-2016-0064

Grimmelikhuijsen, S. (2012). Linking transparency, knowledge and citizen trust in government: an $\begin{array}{llll}\text { experiment. International Review of Administrative Sciences, } & 78(1), \quad 50-73 .\end{array}$ https://doi.org/10.1177/0020852311429667

Habibie, N. (2018). Data 2004-2018: 104 Kepala Daerah Tersandung Korupsi, Paling Banyak di Jawa Timur. Merdeka.Com. https://www.merdeka.com/peristiwa/data-2004-2018-104-kepala-daerahtersandung-korupsi-paling-banyak-di-jawa-timur.html

Hoa, T. T. T., \& Garcia-Zamor, J.-C. (2017). Citizen Participation in Vietnam's Local Government: Impact on Transparency and Accountability. Journal of Public Administration and Governance, 7(4), 38. https://doi.org/10.5296/jpag.v7i4.12044

Kaufmann, D. \& Kraay, A. (2002). Growth without governance. In The World Bank. https://openknowledge.worldbank.org/bitstream/handle/10986/19206/multi0page.pdf?sequence=

KPK. (2020). Statistik Penindakan TPK Berdasarkan Wilayah. Www.Kpk.Go.Id. https://www.kpk.go.id/id/statistik/penindakan/tpk-berdasarkan-wilayah

Laswad, F., Fisher, R., \& Oyelere, P. (2005). Determinants of voluntary Internet financial reporting by local government authorities. Journal of Accounting and Public Policy, 24(2), 101-121. https://doi.org/10.1016/j.jaccpubpol.2004.12.006

Meijer, A. (2013). Understanding the Complex Dynamics of Transparency. 73, 429-439. https://doi.org/10.1111/puar.12032.Understanding

Meijer, A. J., Curtin, D., \& Hillebrandt, M. (2012). Open government: Connecting vision and voice. International Review of Administrative Sciences, 78(1), 10-29. https://doi.org/10.1177/0020852311429533

Moleong, L. J. (2013). Metodologi Penelitian Kualitatif. Remaja Rosdakarya.

Nugraha, F. (2019, November). 22 Dari 34 Provinsi Kepada Daerahnya Terjerat Korupsi. Telisik.Id. https://telisik.id/news/22-dari-34-provinsi-kepala-daerahnya-terjerat-korupsi

Nuryani, \& Firmansyah, A. (2020). Determinants of Transparency in Financial Management on Local Government Websites: Evidence from Indonesia. Humanities and Social Sciences Letters, 8(2), 145-155. https://doi.org/10.18488/journal.73.2020.82.145.155

Partnership, I. B. (2019). Open Budget Survey. In International Budget Partnership (pp. 1-92). https://www.internationalbudget.org/wp-content/uploads/open-budget-survey-report-2019.pdf

Puron-Cid, G., Reddick, C. G., \& Ganapati, S. (2019). Public value of online financial transparency: Financial sustainability and corruption of public officials in the US state governments. International Journal of Public Sector Management, 32(5), 511-533. https://doi.org/10.1108/IJPSM-03-2018-0073

Pusparisa, Y. (2019). 114 Kepala Daerah Terjerat KPK, Paling Banyak Kasus Suap. Katadata.Co.Id. https://katadata.co.id/ariayudhistira/infografik/5e9a50d877ae4/selama-2004-2019-ada-144kepala-daerah-terjerat-kasus-korupsi-di-kpk

Putra, Rediyanto; Ardhiarisca Oryza; Wijayanti Rahma Rina; Pratiwi, B. Y. (2018). Evaluasi perkembangan dan transparansi laporan keuangan e-government pemerintah daerah di indonesia. 2018(Sentika),.

Republik Indonesia. (2010a). Peraturan Menteri Dalam Negeri Nomor 35 Tahun 2010 tentang Pedoman Pengelolaan Pelayanan Informasi dan Dokumentasi di Lingkungan Kementerian Dalam Negeri dan Pemerintah Daerah. Sekretariat Negara.

Republik Indonesia. (2010b). Peraturan Pemerintah Nomor 61 Tahun 2010 tentang Pelaksanaan UU No. 14 Tahun 2008 tentang Keterbukaan Informasi Publik. Sekretariat Negara.

Republik Indonesia. (2008). Undang-Undang Republik Indonesia Nomor 14 Tahun 2008 Tentang Keterbukaan Informasi Publik. Sekretariat Negara.

Republik Indonesia. (2012). Instruksi Menteri Dalam Negeri Republik Indonesia Nomor 188.52/1797/37/SJ/2012 tentang Peningkatan Transparansi Pengelolaan Anggaran Daerah. Sekretariat Negara.

Republik Indonesia. (2015). Instruksi Presiden Republik Indonesia No. 7 Tahun 2015 tentang Aksi dan Pencegahan dan Pemberantasan Korupsi. Sekretariat Negara.

Ritonga, I. T., \& Syamsul. (2016). Mengukur transparansi pengelolaan keuangan daerah di Indonesia: berbasis website. Jurnal Akuntansi Dan Audiiting Indonesia, 20(2). https://doi.org/http://dx.doi.org/10.20885/jaai.vol20.iss2.art4 
Styles, A. K., \& Tennyson, M. (2007). The accessibility of financial reporting of u.s. municipalities on the internet. Journal of Public Budgeting, Accounting \& Financial Management, 19(1), 56-92. https://doi.org/10.1179/str.2007.54.4.006

Syamsul. (2020). POTRET TRANSPARANSI PENGELOLAAN KEUANGAN DAERAH ( TPKD ) DI INDONESIA. Media Riset Akuntansi, Auditing \& Informasi, 20(2), 185-204. https://doi.org/http://dx.doi.org/10.25105/mraai.v20i2.7105

Syamsul, S., \& Ritonga, I. T. (2017). Pengaruh Tata Kelola Pemerintah Daerah Terhadaptransparansi Pengelolaan Keuangan Daerah: Bukti Empiris Pada Pemerintah Provinsi Di Indonesia. Jurnal Akuntansi, 21(3), 448. https://doi.org/10.24912/ja.v21i3.251

Wei Wu, Liang Ma, and W. Y. (2017). Government Transparency and Perceived Social Equity: Assessing the Moderat ing Effect of Cit izen Trust in China. http://hdl.handle.net/10220/44112

Lampiran 1. Indikator Transparansi Pengelolaan Anggaran Daerah (TPAD)

\begin{tabular}{|c|c|c|c|c|c|}
\hline No. & Indikator TPAD & Tersedia & Aksesibilitas & Tepat Waktu & Lengkap \\
\hline 1 & $\begin{array}{l}\text { Ringkasan RKA- } \\
\text { SKPD }\end{array}$ & Ada & Dapat diunduh & $\begin{array}{c}31 \text { November } \\
\text { (tahun berlalu) }\end{array}$ & Seluruh SKPD (OPD) \\
\hline 2 & $\begin{array}{l}\text { Ringkasan RKA- } \\
\text { PPKD }\end{array}$ & Ada & Dapat diunduh & $\begin{array}{c}31 \text { November } \\
\text { (tahun berlalu) }\end{array}$ & PPKD \\
\hline 3 & $\begin{array}{l}\text { Rancangan Perda } \\
\text { APBD }\end{array}$ & Ada & Dapat diunduh & 22 Juni & $\begin{array}{l}\text { Batang tubuh, dan } \\
\text { lampirannya }\end{array}$ \\
\hline 4 & Perda APBD & Ada & Dapat diunduh & 22 Juni & $\begin{array}{l}\text { Batang tubuh, dan } \\
\text { lampirannya }\end{array}$ \\
\hline 5 & $\begin{array}{l}\text { Rancangan Perda } \\
\text { Perubahan APBD }\end{array}$ & Ada & Dapat diunduh & 31 November & $\begin{array}{l}\text { Batang tubuh, dan } \\
\text { lampirannya }\end{array}$ \\
\hline 6 & $\begin{array}{l}\text { Perda Perubahan } \\
\text { APBD }\end{array}$ & Ada & Dapat diunduh & 31 November & $\begin{array}{l}\text { Batang tubuh, dan } \\
\text { lampirannya }\end{array}$ \\
\hline 7 & $\begin{array}{l}\text { Ringkasan DPA- } \\
\text { SKPD }\end{array}$ & Ada & Dapat diunduh & 22 Juni & Seluruh SKPD (OPD) \\
\hline 8 & $\begin{array}{l}\text { Ringkasan DPA- } \\
\text { PPKD }\end{array}$ & Ada & Dapat diunduh & 22 Juni & PPKD \\
\hline 9 & LRA-SKPD & Ada & Dapat diunduh & 31 Agustus & Seluruh SKPD (OPD) \\
\hline 10 & LRA-PPKD & Ada & Dapat diunduh & 31 Agustus & PPKD \\
\hline 11 & LKPD audit & Ada & Dapat diunduh & 31 Agustus & $\begin{array}{c}\text { LO, Neraca, Perubahan } \\
\text { Ekuitas, Laporan Arus Kas, } \\
\text { CaLK, LRA, Laporan } \\
\text { Perubahan SAL }\end{array}$ \\
\hline 12 & Opini atas LKDP & Ada & Dapat diunduh & 31 Agustus & Lembaran Opini \\
\hline
\end{tabular}

Sumber: Inpres RI Nomor 7 Tahun 2015 